\title{
Pengetahuan Ibu tentang Sibling Rivalry pada Anak Usia 5-11 Tahun di Cisarua Kabupaten Bandung Barat
}

\author{
Septian Andriyani ${ }^{*}$, Dadang Darmawan ${ }^{2}$ \\ ${ }^{1}$ Prodi D3 Keperawatan FPOK Universitas Pendidikan Indonesia, Bandung, Indonesia \\ ${ }^{2}$ Akademi Keperawatan RS.Dustira ,Cimahi, Indonesia \\ *Email korespondensi: septianandriyani@upi.edu
}

\section{ARTICLE INFO}

HOW TO CITED:

Andriyani, S., dan Darmawan, D. (2018). Pengetahuan Ibu tentang Sibling Rivalry pada Anak Usia 511 Tahun di Cisarua Kabupaten Bandung Barat. Jurnal Pendidikan Keperawatan Indonesia 4(2), hlm. 162-171

DOI:

10.17509/jpki.v4i2.13708

ARTICLE HISTORY:

Accepted

October 31, 2018

Revised

December 17, 2018

Published

December 31, 2018

\section{A B S T R A K}

Sibling rivalry merupakan persaingan antar saudara untuk memperebutkan perhatian dan kasih sayang orang tua. persaingan terjadi setelah kehadiran adik baru. Permasalahan yang terjadi dalam sibling rivalry adalah kurangnya waktu dan perhatian yang dimiliki oleh suatu keluarga. Angka kekerasan pada anak yang dilakukan oleh saudara kandungnya sendiri yaitu sebesar 26,2\%. Penelitian ini bertujuan untuk mengetahui gambaran pengetahuan ibu tentang sibling rivalry pada anak. Desain penelitian yang digunakan adalah deskriptif kuantitatif. Populasi dalam penelitian ini adalah seluruh ibu yang memiliki anak usia 5-11 tahun yang memiliki adik dengan jarak yang berdekatan dengan jumlah 48 orang.Teknik pengambilan sampel menggunakan teknik purposive sampling. Pengumpulan data dilakukan dengan menggunakan kuesioner yang dibuat oleh peneliti dengan mengacu pada referensi yang sesuai. Hasil penelitian didapatkan bahwa pengetahuan ibu tentang sibling rivalry hampir setengahnya dari responden memiliki pengetahuan cukup sebanyak 18 orang (37,5\%). Hampir setengahnya dari responden memiliki latar belakang pendidikan SD yaitu sebanyak 23 orang (47,9\%), dan sebagian besar berusia 20-35 tahun yaitu sebanyak 35 orang $(72,9 \%)$.Hal ini dapat disebabkan salah satunya oleh sebagian besar ibu masih beranggapan bahwa sibling rivalry adalah sesuatu yang wajar dan sering terjadi pada anak-anak usia 5-11 tahun dan ibu beranggapan bahwa sibling rivalry muncul karena kesalahan orang tua sendiri karena orang tua terlalu tegas dalam menjalankan aturan kepada anak-anaknya. Saran bagi puskesmas yang diharapakan dapat memberikan penyuluhan dan sosialisasi tentang sibling rivalry pada anak dan orang tua secara rutin dan berkesinambungan.

Kata Kunci : Pengetahuan, Sibling Rivalry, Karakteristik 


\begin{abstract}
$A B S T R A C T$
Sibling rivalry is a competition for the attention and affection of parents where such competition occurred after the arrival of the new baby. The problems that occurred in the sibling rivalry is the lack of time and attention that is owned by a family. Child abuse committed by his own brother in the amount of $26.2 \%$. To the knowledge of mothers about sibling rivalry is very important because if it is not handled well the children will continue to compete and jealous of one another and can be continuous throughout life the child. This research aims to describe mother's knowledge of sibling rivalry in children. The research design used is descriptive quantitative. The population in this research are all mothers have a children aged 5-11 years who has a younger brother with closely spaced and the total is 55 people and the samples of this research is 48 people by using purposive sampling technique. Data was collected by using a questionnaire designed by the researchers with reference to the appropriate reference. The result showed that the level of knowledge of mothers about sibling rivalry almost half of the respondents have sufficient knowledge as many as 18 people (37.5\%). Almost half of the respondents have a background in elementary education as many as 23 people (47.9\%), and mostly aged 20-35 years as many as 35 people (72.9\%). Advice for health centers is expected to provide counseling and socialization of sibling rivalry in children regularly and continuously.
\end{abstract}

Keywords : Knowledge, Sibling Rivalry, Characteristics

\section{PENDAHULUAN}

Anak bukanlah miniatur orang dewasa karena anak mempunyai ciri khas yang berbeda dengan orang dewasa, selain itu anak memerlukan perhatian khusus untuk optimalisasi tumbuh kembang anak (Eni, 2008). Keluarga merupakan tempat utama dimana seorang anak tumbuh dan berkembang. Di Indonesia mempunyai anak lebih dari satu merupakan hal yang umum. Masyarakat Indonesia menganggap bahwa anak merupakan sumber kebahagiaan, bahkan di beberapa daerah ada anggapan "banyak anak banyak rejeki" (Anayanti, 2013). Ketika orang tua memutuskan untuk memiliki lebih dari satu anak, maka ada kehadiran sibling dalam kehidupan anak pertama.Faktor keluarga merupakan faktor yang sangat mempengaruhi perkembangan anak, apabila hubungan antar sibling baik maka hubungan keluargapun akan cenderung baik pula. Sebaliknya bila hubungan antar sibling kurang baik, itu akan mengganggu hubungan sosial dan pribadi anggota keluarga lainnya (Setiawan, 2013).

Sibling dalam konsep psikologi diartikan sebagai saudara laki-laki atau perempuan yang tinggal bersama dalam satu pengasuhan orangtua yang sama. Sibling dapat merupakan saudara kandung, saudara tiri atau saudara adopsi (Anayanti 2013). Kehadiran adik bagi anak pertama atau anak sulung dapat memunculkan berbagai macam kecemburuan atau persaingan yang berbeda satu sama lainnya. Cemburu pertama kali terlihat ketika kakak mempunyai adik baru. Sebelum adiknya lahir, kakaknya merasa orang tua menjadi milik sepenuhnya. Kakaknya tidak perlu bersaing dengan orang lain untuk mendapatkan kasih sayang atau perhatian. Lahirnya saudara kandung membuat kakak merasa waktu dan perhatian ibu kurang. Selain itu, kakak takut tidak lagi disayang oleh orang tuanya. Kecemburuan atau persaingan yang terjadi antara saudara kandung disebut dengan istilah sibling rivalry (Setiawan,2013).

Sibling rivalry adalah kecemburuan, persaingan dan pertempuran antara saudara laki-laki dan saudara perempuan, masalah sering dimulai tepat setelah kelahiran anak kedua (Boyse, 2011). Persaingan umumnya terjadi ketika anak masih kecil dan persaingan akan menurun ketika anak semakin dewasa. Hal ini juga terjadi karena jarak usia antar anak sangat dekat (Zolten, 2006). Suherni (2009) sibling rivalry atau perselisihan yang terjadi pada anak-anak tersebut ada- 
adalah hal yang biasa bagi anak-anak usia antara 5-11 tahun. Bahkan kurang dari 5 tahun pun sudah sangat mudah terjadi sibling rivalry itu, namun persaingan antar saudara cenderung memuncak ketika adiknya berusia 3 atau 4 tahun.

Sibling rivalry menjadi sumber masalah jika rasa permusuhan antar individu semakin dalam. Pertengkaran akan semakin membahayakan masing-masing individu, salah satunya anak merasa rendah diri dan mungkin akan melakukan tindakan yang menyakiti saudaranya (Nopijar, 2009). Sibling rivalry dapat dipengaruhi oleh sikap dan perilaku orang tua. Kadang-kadang, orang tua hanya memihak kepada satu anak. Faktor-faktor lain yang mempengaruhi sibling rivalry pada anak adalah selisih usia antar saudara, jenis kelamin, jumlah saudara, posisi dalam keluarga, dan temperamen individual (Oesterreich, 2014). Dampak sibling rivalry pada anak yaitu adanya tingkah laku regresi. Regresi yang dimaksud adalah kembali pada taraf perkembangan yang lebih dahulu. Tingkah laku anak ini biasanya terjadi supaya anak mendapatkan perhatian lebih dari orang tuanya. Bentuk regresi yang biasa ditunjukkan yaitu gangguan terhadap pengendalian buang air besar dan buang air kecil serta tendensi perilaku seperti bayi seperti memasukkan jari kedalam mulut. Sedangkan dampak pada saudaranya yaitu agresi. Agresi adalah setiap usaha yang disengaja untuk menyakiti saudaranya, baik secara fisik atau verbal. Agresi fisik tersebut seperti memukul, menendang, meludah, mencakar terhadap adiknya. Sedangkan agresi verbal yaitu menyalahkan adiknya saat tidak nyaman terhadap sesuatu (Citra, Ayu 2013).

Pola asuh orang tua sangat penting dalam menghadapi masalah pada anak, pola asuh orang tua pada kehidupan anak tidak hanya mempengaruhi kehidupan salah satu anak, tetapi juga hubungan antar sibling. Dalam sibling rivalry anak tidak hanya membandingkan dirinya dengan saudara kandungnya yang lain melainkan ia juga menilai bagaimana orangtuanya membandingkan dengan saudaranya yang lain. Sibling rivalry bisa menghasilkan manfaat, tetapi biasanya anak merasa direndahkan oleh orang tuanya yang lebih suka pada anak lain. Banyak permasalahan yang timbul karena pola asuh yang kurang tepat misalnya memberikan perhatian yang lebih pada anak yang lain sehingga akan menimbulkan reaksi sibling rivalry (Agustin, 2013). Permasalahan yang sering terjadi dalam sibling rivalry adalah kurangnya waktu dan perhatian yang dimiliki oleh suatu keluarga. Seorang kakak yang iri terhadap adiknya menganggap adik sebagai penyebab hilangnya kasih sayang dan perhatian yang selama ini menjadi miliknya seorang. Bagi anakanak yang menjadi bahan yang diperebutkan adalah waktu, perhatian, cinta, dan penerimaan yang diberikan orang tua kepada setiap anak (Prayogi, 2014). Pengetahuan ibu tentang sibling rivalry merupakan hal yang sangat penting terutama dalam hal pencegahan dan cara penanganan yang tepat. Secara teori sibling rivalry merupakan hal yang biasa yang terjadi di dalam keluarga namun sibling rivalry harus mendapatkan perhatian orang tua karena penanganan yang tidak tepat dapat menimbulkan masalah yang berkelanjutan. Bila pertengkaran yang terus menerus dipupuk sejak kecil akan terus meruncing saat anak-anak beranjak dewasa, anak-anak akan terus bersaing dan saling mendengki dan perselisihan saudara kandung (sibling rivalry) bisa berkelanjutan sepanjang hidup anak. Bahkan ada kejadian saudara kandung saling membunuh karena memperebutkan warisan. Namun, jika masih berada dalam taraf yang wajar dan diatasi dengan cara yang tepat, maka sibling rivalry masih memiliki efek yang positif. Anak dapat berlatih mengatasi masalah, mengontrol emosi, belajar etika meminta maaf, serta bisa lebih jernih dalam menilai serta mencari solusi masalah (Nopijar, 2009).

Hasil studi pendahuluan yang telah dilakukan pada bulan Januari 2017 di RW 03 Desa Pasirlangu Kec Cisarua Kab Bandung Barat kepada 10 orang ibu yang mempunyai anak usia 5-11 tahun dilakukan wawancara tentang sibling rivalry, dari hasil wawancara tersebut terdapat 6 orang ibu mengatakan bahwa sibling rivalry atau persaingan antar saudara yaitu persaingan yang terjadi pada anak-anak untuk memperebutkan perhatian dari orang tuanya namun ibu tidak 
tahu dampak kedepanya serta tidak mengetahui pencegahannya, sedangkan 4 orang ibu mengatakan sibling rivalry atau persaingan antar saudara merupakan persaingan yang terjadi karena memperebutkan kasih sayang dan perhatian dari orang tua namun ibu kurang memahaminya dampak dan cara pencegahannya. Dari 10 orang ibu tersebut, 3 orang ibu mengatakan anakanaknya sering berkelahi dan berebut mainan, kakaknya yang awalnya tidak mengompol menjadi ngompol lagi, sering membantah kepada orang tuanya, dan terkadang merusak mainan milik saudaranya. 5 orang ibu mengatakan anakanaknya jarang bertengkar, namun kakaknya sering menangis tanpa sebab, dan 2 orang ibu mengatakan anak-anaknya tidak pernah bertengkar dan kakaknya selalu berbagi kepada adiknya itu karena orang tua selalu memperlakukan sama terhadap anak-anaknya.Berdasarkan fenomena diatas, penulis sangat tertarik untuk melakukan penelitian tentang Bagaimana gambaran pengetahuan ibu tentang sibling rivalry pada anak usia 5-11 tahun berdasarkan karakteristik usia dan pendidikan di RW 03 Desa Pasirlangu Kec Cisarua Kab Bandung Barat.

\section{METODE}

Desain penelitian yang digunakan dalam penelitian ini adalah deskriptif kuantitatif yaitu untuk menggambarkan pengetahuan ibu tentang sibling rivalry pada anak usia 5-11 tahun di Desa Pasirlanggu Kabupaten Bandung Barat. Populasi dalam penelitian ini adalah seluruh ibu yang memiliki anak usia 5-11 tahun yang memiliki adik dengan jarak usia berdekatan di RW 03 Desa Pasirlangu dengan jumlah 55 ibu. Teknik sampel yang digunakan adalah purposive sampling yaitu sebanyak 48 orang ibu yang mempunyai anak usia 5-11 tahun, mempunyai adik dengan perbedaan usia 2-4 tahun.

Hasil perhitungan proporsional responden bahwa di RW 03 Desa Pasirlangu terdapat 5 RT dengan proporsi sebagaimana disajikan pada table 1 .

Instrumen yang digunakan dalam penelitian ini adalah kuesioner berbentuk pertanyaan tertutup. Kuesioner dibuat sendiri oleh peneliti dengan mengacu pada sumber referensi yang sesuai dengan kajian. Data diolah dengan menggunakan analisis univariat bertujuan untuk mengetahui distribusi, frekuensi, dan proporsi dari variabel karakteristik ibu yaitu usia dan pendidikan serta menggunakan analisa tabulasi silang menggunakan perangkat lunak komputer.

\section{HASIL DAN PEMBAHASAN \\ 1. Distribusi Frekuensi Pengetahuan Di RW 03 Desa Pasirlangu.}

Table 2 menunjukkan bahwa responden memilki pengetahuan yang cukup tentang sibling rivalry $(37,5 \%)$. Sebagian besar ibu masih beranggapan bahwa sibling rivalry adalah sesuatu yang wajar dan sering terjadi pada anak-anak usia 5-11 tahun dan ibu beranggapan bahwa sibling rivalry muncul karena kesalahan orang tua sendiri karena orang tua terlalu tegas dalam menjalankan aturan kepada anak-anaknya.

Hal ini sesuai dengan penelitian yang dilakukan oleh Athira (2012) tentang pengetahuan dan sikap ibu tentang sibling rivalry di Rumah Sakit Mangalore bahwa 90,3\% ibu memiliki pengetahuan yang cukup tentang sibling rivalry. Sibling rivalry adalah kompetisi antara saudara kandung untuk mendapatkan cinta kasih, afeksi dan perhatian dari satu atau kedua orang tuanya (Suherni, 2009). sibling rivalry menunjukkan adanya rasa cemburu atau persaingan antar saudara untuk mendapatkan perhatian orangtua (Lestari,2017). Sibling rivarlry ini merupakan dimensi dari kualitas sibling relationship. Sibling rivalry biasa terjadi pada keluarga yang memiliki anak lebih dari satu. Oleh karena itu orang tua mempunyai peran penting untuk mencegah serta mengurangi perkelahian antara saudara kandung dengan pengetahuan yang baik tentang sibling rivalry orang tua dapat mengenali tanda reaksi sibling rivalry. Hal tersebut berbeda dengan hasil penelitian yang dilakukan oleh Siregar (2012) tentang Pengetahuan Dan Sikap Ibu Tentang Sibling Rivalry Di klinik Bersalin Hanafi kel. Tanjung Gusta Kec. MedanHelvetia, hasil penelitian ini menunjukkan bahwa pengetahuan ibu tentang sibling rivalry mayoritas berpengetahuan kurang sebanyak 20 
responden (66\%). Hal ini disebabkan karena masih kurangnya informasi yang didapatkan oleh ibu tentang sibling rivalry. Ibu yang memiliki pengetahuan yang baik tentang sibling rivalry maka akan segera mengenali reaksi sibling rivalry pada anaknya terutama pada awal-awal kelahiran bayinya dan mengetahui cara yang tepat mengurangi efeknya terhadap anaknya yang lain.

Adapun faktor-faktor yang mempengaruhi pengetahuan yaitu pendidikan, usia dan pekerjaan. Dengan pendidikan yang tinggi maka seseorang akan lebih mudah mendapatkan informasi terutama tentang sibling rivalry. Usia dapat mempengaruhi terhadap daya tangkap dan pola pikir seseorang, semakin bertambah usia akan semakin berkembang pula daya tangkap dan pola pikirnya. Pekerjaan bagi ibu-ibu akan mempunyai pengaruh terhadap kehidupan keluarga, ketika ibu jarang di rumah maka ibu tidak akan memperhatikan perkembangan anaknya.
Berdasarkan analisis dari beberapa indikator penelitian bahwa $85,4 \%$ responden menjawab dengan benar pada indikator "Mengatasi Sibling Rivalry" dan sebanyak $77 \%$ responden yang menjawab salah yaitu pada indikator "Pengertian Sibling Rivalry" masih banyak yang menjawab bahwa sibling rivalry adalah perasaan cemburu atau benci karena kesalahan orang tua padahal sibling rivalry sendiri adalah perasaan cemburu atau benci karena kehadiran adik. sibling rivalry menunjukkan adanya persaingan antar saudara karena perbedaan perlakuan orangtua (Simatupang \& Handayani, 2015). Lamanna dan Riedmann (2012) juga menyatakan bahwa sibling rivalry disebabkan oleh adanya persaingan untuk memperebutkan kasih sayang orangtua. Aspek-aspek yang terdapat dalam dimensi sibling rivalry adalah keberpihakan orangtua dan kompetisi untuk mendapatkan perhatian orangtua (Lestari,2017). Ibu belum begitu familiar dengan istilah sibling rivalry dan beranggapan

Tabel 1. Proporsi Responden di RW 03 Desa Pasirlangu

\begin{tabular}{cccc}
\hline No & RT & Rumus & Besar Responden \\
\hline 1 & 01 & $\frac{9 \times 48}{55}$ & 8 \\
2 & 02 & $\frac{7 x 48}{55}$ & 6 \\
3 & 03 & $\frac{14 x 48}{55}$ & 12 \\
4 & 04 & $\frac{13 x 48}{55}$ & 11 \\
5 & 05 & $\frac{12 x 48}{55}$ & 11 \\
\hline
\end{tabular}

Tabel 2. Distribusi Frekuensi Tingkat Pengetahuan Di RW 03 Desa Pasirlangu kecamatan Cisarua Tahun 2015

\begin{tabular}{ccc}
\hline Tingkat Pengetahuan & Frekuensi & Persentase \% \\
\hline Baik & 17 & 35,4 \\
Cukup & 18 & 37,5 \\
Kurang & 13 & 27,1 \\
\hline Total & 48 & 100 \\
\hline
\end{tabular}


bahwa itu adalah hal yang wajar dan biasa terjadi pada setiap anak dan ibu beranggapan bahwa membanding-bandingkan anak yang satu dengan yang lainnya adalah hal yang tepat agar anak bisa menjadi lebih baik lagi baik itu dalam bersikap maupun dalam prestasi di sekolah. Ibu seringkali memarahi anak yang salah dan ketika anak memperebutkan mainan yang sama ibu akan memberikan pada anak yang lebih kecil, itu karena kakak harus bisa mengalah kepada adik, namun tanpa ibu sadari hal itu dapat memicu terjadinya sibling rivalry pada anak.

Selain itu bahwa individu yang berada pada tahap perkembangan yang berbeda, mengalami perkembangan fisik, kognitif, dan psikososial yang berbeda pula. Saudara dengan beda usia 3 tahun lebih, memiliki tahap perkembangan yang berbeda. Kakak yang berusia 3-6 tahun sudah berada pada masa perkembangan anak awal, sementara adik yang baru lahir berada pada masa perkembangan bayi (Papalia dan Feldman 2012). Patz (2013) dalam artikelnya mengatakan bahwa anak dengan tahap perkembangan berbeda cenderung memiliki mainan, teman, atau hobi yang berbeda pula. Hal tersebut menyebabkan anak kesulitan memiliki hubungan yang dekat dengan saudaranya.

Sementara itu, artikel Best Age Gap between Siblings mengatakan bahwa anak dengan beda usia 4 tahun lebih jarang mengalami sibling rivalry. Coles (2006) juga mengatakan bahwa beda usia yang jauh antar saudara menyebabkan hubungan yang positif. Hal ini disebabkan oleh kakak sudah dapat berperan sebagai orangtua bagi adiknya.

Ibu harus mengenali tanda-tanda reaksi sibling rivalry pada anak dimana anak akan secara terang-terangan melakukan kekerasan terhadap adiknya, memukul adiknya, mendorong bayi dari pangkuan ibu, ngompol, menangis tanpa sebab. Untuk itu penting bagi ibu mengetahui tentang sibling rivalry. Sibling rivalry dapat disebabkan oleh beberapa faktor salah satunya adalah pengetahuan ibu, ibu harus mengetahui tentang hal-hal negatif yang dilakukan oleh anak kepada kakak maupun adiknya baik di rumah maupun di sekolah karena tanpa ibu sadari bisa saja anak sedang mengalami sibling rivalry
(Boyse, 2011). Sibling rivalry merupakan hal yang biasa yang terjadi di dalam keluarga namun sibling rivalry harus mendapatkan perhatian orang tua karena penanganan yang tidak tepat dapat menimbulkan masalah yang berkelanjutan.

Bila pertengkaran yang terus menerus dipupuk sejak kecil akan terus meruncing saat anak-anak beranjak dewasa, anak-anak akan terus bersaing dan saling mendengki dan perselisihan saudara kandung (sibling rivalry) bisa berkelanjutan sepanjang hidup anak (Anandyah, 2012). Saudara kandung mempunyai pengaruh penting pada pengembangan individu dan kesejahteraan ditunjukkan dengan perilaku dan gaya interaksi (Tucker dan Finkelhor,2017).

Jumlah saudara kandung juga dapat memberikan pengaruh tersendiri dalam perkembangan anak. Anak dengan jumlah saudara sedikit cenderung lebih sering bertengkar dibanding anak yang memiliki saudara kandung banyak (Putri, 2013). Kurangnya pengetahuan ibu tentang sibling rivalry dapat disebabkan karena ibu kurang mendapatkan informasi mengenai sibling rivalry pada anak dan belum pernah diadakan penyuluhan di Desa Pasrilangu khususnya di RW 03 tentang sibling rivalry pada anak.

\section{Distribusi Frekuensi Tingkat Pengetahuan Ibu Di RW 03 Desa Pasirlangu Kecamatan Cisarua Berdasarkan Tingkat Pendidikan.}

Hasil penelitian menunjukan bahwa distribusi tingkat pendidikan responden yaitu memiliki latar belakang pendidikan rendah (SD) sebanyak 23 responden (47,9\%). Tingkat pendidikan seseorang akan mempengaruhi pengetahuan yang dimilikinya. Responden dengan pendidikan yang tinggi kemungkinan akan memiliki pengetahuan yang lebih baik tentang sibling rivalry dibandingkan dengan yang berpendidikan rendah akan memiliki pengetahuan yang kurang tentang sibling rivalry.

Hal ini dapat dijelaskan bahwa pengetahuan dapat menggambarkan wawasan seseorang yang dipengaruhi oleh tingkat pendidikan, dimana tingkat pendidikan tersebut berpengaruh terhadap penerimaan atau pemahaman serta daya ingat seseorang terhadap informasi yang pernah diperoleh. Hal tersebut berkaitan dengan pem- 
berian respon seseorang terhadap suatu stimulus yang datang dari luar. Orang yang berpendidikan tinggi akan memberikan respon yang lebih rasional terhadap informasi yang datang dan akan berpikir sejauh mana keuntungan yang akan didapatkannya. Semakin tinggi pendidikan seseorang semakin mudah pula mereka menerima informasi, dan pada akhirnya semakin banyak pula pengetahuan yang dimilikinya. Sebaliknya jika seseorang tingkat pendidikannya rendah, maka akan menghambat perkembangan sikap seseorang terhadap penerimaan informasi dan nilai-nilai yang baru diperkenalkan (Wawan dan Dewi, 2010).

Berdasarkan penelitian yang dilakukan oleh Rejeki Sri (2012) tentang pengetahuan ibu dan reaksi sibling rivalry pada anak usia pra sekolah (3-5 tahun), bahwa pendidikan yang lebih rendah mempengaruhi ibu dalam mendapatkan pemahaman dan pengalaman baru dalam hal ini pengenalan mengenai tanda-tanda dini reaksi sibling rivalry dan penangananannya. Semakin tinggi pendidikan seseorang maka pengetahuannya akan semakin luas atau baik, selain itu semakin tinggi pendidikan seseorang akan mempermudah orang tersebut dalam menerima informasi.

Penelitian yang dilakukan oleh Setiawan (2013) tentang Hubungan Persiapan Kelahiran Adik Baru Dengan Perilaku Sibling Rivalry Pada Anak Usia Toddler didapatkan $80 \%$ ibu berpendidikan SMA dan memiliki pengetahuan yang baik tentang sibling rivalry. Tingkat pendidikan seseorang juga memiliki peran positif terhadap pendidikan dalam keluarga. Tingkat pendidikan turut menentukan mudah tidaknya seseorang menyerap dan memahami pengetahuan yang mereka peroleh, pada umumnya semakin tinggi pendidikan seseorang maka semakin baik pula pengetahuanya.

Pengetahuan sangat erat hubungannya dengan pendidikan, dimana diharapkan bahwa dengan pendidikan yang tinggi maka orang tersebut akan semakin luas pula pengetahuanya. Akan tetapi perlu ditekankan, bukan berarti seseorang yang berpendidikan rendah mutlak berpengetahuan rendah pula. Hal ini mengingat bahwa peningkatan pengetahuan tidak mutlak diperoleh dari pendidikan formal saja, akan tetapi dapat di- diperoleh melalui pendidikan non formal (Wawan dan Dewi, 2010).

Pendidikan seseorang sangat mempengaruhi pengetahuan, karena semakin tinggi pendidikan seseorang maka semakin banyak pula pengalaman dan informasi yang didapat, seseorang yang memiliki pendidikan yang tinggi akan lebih mudah menerima informasi dibandingkan dengan yang berpendidikan rendah. Pendidikan ibu sangat mempengaruhi ibu dalam memberikan perhatian yang sama pada anak. Anak yang merasa tidak menerima perhatian, disiplin, respon dan perlakuan sama seperti saudaranya maka anak akan menjadi marah dan iri terhadap saudaranya

\section{Distribusi Frekuensi Tingkat Pengetahuan Pada ibu Di RW 03 Desa Pasirlangu Kecama- tan Cisarua Berdasarkan Tingkat Usia}

Hasil penelitian menunjukkan bahwa pada responden yang berusia 20-35 tahun terdapat 14 responden $(29,2 \%)$ mempunyai pengetahuan baik, dan pada responden yang berusia $>35$ tahun terdapat 7 responden $(14,6 \%)$ yang mempunyai pengetahuan yang kurang. Dari tabel diatas menunjukan bahwa sebagian dari responden berusia 20-35 tahun yaitu sebanyak 35 orang $(72,9 \%)$, dan pada usia tersebut banyak yang memiliki anak usia 5-11 tahun yang memiliki adik dengan jarak yang berdekatan (2-4 tahun).

Pada usia tersebut mendukung dalam mendapatkan sumber infomasi lebih banyak dan lebih mudah dikarenakan pada usia tersebut ratarata sudah familiar dalam penggunaan internet ataupun media lain dalam pengaksesan informasi. Pada usia tersebut sebagian ibu sudah mengenal dan bisa mengakses internet untuk mendapatkan informasi yang lebih banyak. Pada usia $<20$ tahun di RW 03 mayoritas ibu hanya memiliki satu anak saja dan hanya dua ibu yang memiliki anak usia 5-11 tahun yang memiliki adik. Dari hasil penelitian usia $<20$ tahun memiliki pengetahuan yang baik tentang sibling rivalry hal itu disebabkan karena di usia tersebut ibu sudah mulai mengenal dan mengakses internet jadi dapat dengan mudah menerima informasi.

Berdasarkan hasil survey yang dilakukan oleh APJII (Asosiasi Penyelenggara Jasa Inter- 
net Indonesia) tahun 2012 mengindikasikan jumlah pengguna Internet di seluruh Indonesia pada tahun 2012 ini sudah mencapai 63 juta orang. Dominasi terbesar berasal dari kelompok umur 12- 35 tahun, yaitu sebesar $60 \%$ dari seluruh pengguna Internet. Pengguna Internet pada usia ini adalah digital natives, yaitu kelompok usia yang lahir dan dibesarkan dalam lingkungan yang sudah serba terkomputerisasi, terbiasa dengan informasi dan data digital serta saling terkoneksi dalam sebuah sistem atau jaringan.

Hal tersebut menyebabkan pengetahuan usia 20-35 tahun lebih baik dibandingkan dengan usia $>35$ tahun hal ini disebabkan usia 20-35 tahun merupakan merupakan usia produktif dimana usia tersebut sudah mulai matang berpikir dan dapat dengan mudah mencerna informasi yang didapatkan. Sedangkan pada usia $>35$ tahun puncak kematangan kognisi mulai menurun ditandai dengan seringnya lupa dan masih awam terhadap pengaksesan informasi lebih luas menggunakan internet ataupun media lain. Dari beberapa penelitian yang telah dilakukan bahwa kecepatan memproses informasi mengalami penurunan pada masa dewasa akhir.
Penelitian lain juga membuktikan bahwa orang-orang dewasa lanjut kurang mampu mengeluarkan kembali informasi yang telah disimpan dalam ingatannya (Arimindani,2012).

Hasil penelitian yang dilakukan oleh Nisa Zahrotun (2010) tentang Hubungan Sikap Orang Tua Dengan Kejadian Sibling Rivalry Pada Anak Usia Toddler Di Desa Gendong Kulon Babat Lamongan, didapatakan data bahwa $75 \%$ ibu berusia 20-35 tahun dan memiliki sikap yang baik. Usia ini merupakan salah satu hal yang mempengaruhi seseorang untuk belajar dan menjadi lebih tahu, karena sangat produktif sehingga informasi yang diperoleh dari mana dan dari siapapun terutama mengenai anak bisa dengan mudah diterima dan diterapkan pada anaknya.Pengetahuan seseorang belum tentu dipengaruhi oleh usia karena semakin tinggi usia seseorang belum tentu semakin baik pula pengetahuannya. Hal ini disebabkan responden bisa menerima informasi mengenai sibling rivalry melalui pengalaman atau lingkungannya.

Tabel 3. Distribusi Frekuensi Tingkat Pengetahuan Pada ibu di RW 03 Desa Pasirlangu

\begin{tabular}{|c|c|c|c|c|c|c|c|c|}
\hline \multirow{3}{*}{$\begin{array}{c}\text { Tingkat } \\
\text { Pengetahuan }\end{array}$} & \multicolumn{6}{|c|}{ Usia } & \multirow{2}{*}{\multicolumn{2}{|c|}{ Total }} \\
\hline & \multicolumn{2}{|c|}{$<20$ tahun } & \multicolumn{2}{|c|}{ 20-35 tahun } & \multicolumn{2}{|c|}{$>35$ tahun } & & \\
\hline & $\mathrm{N}$ & $\begin{array}{c}\text { Persentase } \\
(\%)\end{array}$ & $\mathrm{n}$ & $\begin{array}{c}\text { Persentase } \\
(\%)\end{array}$ & $\mathrm{n}$ & $\begin{array}{c}\text { Persentase } \\
(\%)\end{array}$ & $\mathrm{N} P r$ & $(\%)$ \\
\hline Baik & 1 & 2,1 & 14 & 29,2 & 2 & 4,2 & 17 & 35,4 \\
\hline Cukup & 0 & 0 & 16 & 33,3 & 2 & 4,2 & 18 & 37,5 \\
\hline Kurang & 1 & 2,1 & 5 & 10,4 & 7 & 14,6 & 13 & 27,1 \\
\hline Total & 2 & 4,2 & 35 & 72,9 & 11 & 22,9 & 48 & 100 \\
\hline
\end{tabular}




\section{SIMPULAN DAN SARAN}

Berdasarkan hasil penelitian dapat disimpulkan bahwa Tingkat pengetahuan ibu tentang sibling rivalry pada anak hampir setengahnya dari responden memiliki pengetahuan yang cukup yaitu sebanyak 18 responden $(37,5 \%)$. Responden di RW 03 hampir setengahnya memiliki latar belakang pendidikan SD yaitu sebanyak 23 orang $(47,9 \%)$. Responden di RW 03 sebagian besar berusia 20-35 tahun yaitu sebanyak 35 orang $(72,9 \%)$.

Berdasarkan simpulan tersebut, maka diharapkan Puskesmas dapat memberikan

\section{REFERENSI}

Agustin, Nur. 2013. Hubungan Pola Asuh Dominan Orang Tua dengan Sibling Rivalry Anak Usia Prasekolah [serial online]. Tersedia dari: URL: http:// www.digilib.umpo.ac.id

Anayanti. 2013. Sibling Rivalry pada Anak Usia Dini [serial online]. Tersedia dari : URL: http://www.prepository.uksw.edu

Athira, Chandran. 2012. A Study on Knowledge and Attitude of Mothers Regarding Sibling Rivalry in a Selected Hospital and PHC in Mangalore with the view to Develop a Self Instructional Module [serial online]. Tersedia dari : URL: http:// connection.ebscohost.org

Boyse, Kyla. 2011. What is Sibling Rivalry [serial online]. Tersedia dari : URL: http:// www.med.umich.edu

Citra, Ayu. 2013. Dampak Sibling Rivalry (Persaingan Antar Saudara) pada Anak Usia Dini [serial online]. Tersedia dari : URL: http://www.lib.unnes.go.id

Eni, Hidayati. 2008. Hubungan Pengetahuan Ibu Tentang Perkembangan Psikomotor Anak Usia 3.5 Tahun Di Desa Sarirejo Kec. Guntur Kab. Demak, [serial online]. Tersedia dari : URL: http://www.jurnal.unimus.ac.id

Hardy, Marjorie, dkk. 2009. Personal Experience and Perceived Acceptability of Sibling Aggression [serial online]. Tersedia dari : penyuluhan dan sosialisasi pentingnya pemahaman orang tua tentang sibling rivalry secara periodik kepada warga di wiliyah binaannya bersama dengan kader yang ada di Desa Pasirlangu. Sosialisasi tersebut diprioritaskan kepada para ibu yang memiliki anak lebih dari satu dengan jarak yang dekat baik secara kelompok maupun individu serta didukung dengan penyebaran informasi mengenai pencegahannya, tanda-tanda dini reaksi sibling rivalry dan penanganannya baik melalui media elektronik dan media cetak seperti leaflet, poster dan sebagainya.

URL: http://www.repository.uinjkt.ac.id

Fauziyah, R.., Salimo,H.,, Murti,B.,(2017), Influence Of Psycho-Socio-Economic Factors, Parenting Style, And Sibling Rivalry, On Mental And Emotional Development Of Preschool Children In Sidoarjo District. Journal of Maternal and Child Health (2017), 2(3): 233-244

Lestari,V., (2017), Gambaran Pola Sibling Relationship Pada Adik Usia Remaja Dengan Kakak Usia Dewasa Awal, Jurnal Muara Ilmu Sosial, Humaniora, dan Seni Vol. 1, No. 2, Oktober 2017: hlm 100-108

Nopijar. 2012. Sibling Rivalry pada Anak Kembar yang Berbeda Jenis Kelamin [serial online]. Tersedia dari : URL: http:// www.gunadarma.ac.id

Oesterreich, Lesia. 2014. Getting Along: Sibling Fights [serial online]. Tersedia dari : URL: http://www.a-better-child.org

Papalia, D. E., \& Feldman, R. D. (2012). Experience human development (12th ed.). New York, NY: McGraw-Hill.

Patz, A. (2013, July). Ready for another child: Expert and moms weigh in on the ideal age difference between kids. Parenting. Retrieved from http://www.parenting.com/ article/ready-for-another-child

Pendley, Jennifer Shroff. 2012. About Sibling Rivalry [serial online]. Tersedia dari : URL: http://www.kidshealth.org 
Putri A (2013). Dampak sibling rivalry (persaingan saudara kandung) pada anak usia dini. Skripsi. Universitas Negeri Semarang

Prayogi. 2014. Mengatur Jarak Usia Ideal Kakak Adik [serial online]. Tersedia dari : URL: http://www.republika.co.id

Setiawan, Wawan. 2013. Hubungan Persiapan Kelahiran Adik Baru dengan Perilaku Sibling Rivalry Pada Anak Usia Toddler [serial online]. Tersedia dari : URL: http:// www.keperawatan.unsoed.ac.id

Wawan dan Dewi. 2010. Teori \& Pengukuran Pengetahuan, Sikap, dan Perilaku Manusia. Yogyakarta : Nuha Medika
Tucker C.J, David Finkelhor,D., (2017) The State of Interventions for Sibling Conflict and Aggression: A Systematic Review, Trauma, Violence, \& Abuse, Vol. 18(4) 396-406

Zolten, Kristin dan Nicholas Long. 2006. Sibling Rivalry Among Older Children [serial online]. Tersedia dari : URL: http:// www.parenting-ed.org 